\title{
Crown rust on oat genotypes with different levels of resistance: damages and losses
}

\author{
Maike Lovatto ${ }^{1}$ (i) Gerarda Beatriz Pinto da Silva ${ }^{1,3}$ (i) Filipe Kalikoski Coelho ${ }^{1}$ (i) \\ José Antonio Martinelli ${ }^{2}$ (D) Marcelo Teixeira Pacheco ${ }^{1}$ (D) Luiz Carlos Federizzi ${ }^{1}$ (i) \\ Carla Andréa Delatorre ${ }^{1^{*}}$ (D)
}

${ }^{1}$ Universidade Federal do Rio Grande do Sul (UFRGS), Faculdade de Agronomia, Departamento de Plantas de Lavoura, 91501-970, Porto Alegre, RS, Brasil. E-mail: cadtorre@ufrgs.br. "Corresponding author.

${ }^{2}$ Universidade Federal do Rio Grande do Sul (UFRGS), Faculdade de Agronomia, Departamento de Fitossanidade, Porto Alegre, RS, Brasil. ${ }^{3}$ GDM Genética do Brasil, Porto Nacional, TO, Brasil.

\begin{abstract}
The evolution in virulence of Puccinia coronata $f$. sp. avenae has challenged the genetic resistance to crown rust in oat genotypes. New resistance sources are constantly required for yield stabilization and costs reduction. This study aimed to characterize the crown rust resistance of oat genotypes and the disease's productive and economic impact. Experiments were conducted in two environments, with and without chemical control. Resistance was measured by disease progress, apparent rate of infection, final severity and pustule size. Damages were based on reduction of yield, 1000 grain mass and hectoliter mass. UFRGS16Q6030-2 was immune. In both environments, UFRGS166091-2 and URS Brava exhibited the greatest level of resistance and the smallest grain yield reduction, while URS 22 was highly susceptible, reducing more than $70 \%$ of its grain yield. These results surpass the negative impacts of the disease previously reported in oats, particularly related to grain yield. The data presented in this paper highlighted the importance of genetic resistance, particularly partial resistance, for maintaining oat genetic yield potential, reducing environmental contamination with less fungicides, and increasing economic gains with oat cultivation.
\end{abstract}

Key words: Avena sativa, Puccinia coronataf. sp. avenae, genetic resistance, economic analysis.

Ferrugem da folha sobre genótipos de aveia com diferentes níveis de resistência: danos e perdas

RESUMO: A evolução da virulência de Puccinia coronata f. sp. avenae desafia a resistência genética de cultivares de aveia à ferrugem da folha. Novas fontes de resistência são constantemente necessárias para estabilizar a produção e reduzir custos. Os objetivos desse estudo foram caracterizar a resistência de seis genótipos de aveia à ferrugem da folha e avaliar o impacto produtivo e econômico causado pela doença. Foram conduzidos ensaios em dois ambientes com e sem o controle químico. A resistência foi medida via progresso da doença, taxa aparente de infecção, severidade final e tamanho da pústula. As perdas foram avaliadas em rendimento, massa de mil grãos e massa do hectolitro. UFRGS 16Q6030-2 foi imune. Em ambos os ambientes, UFRGS 166091-2 e URS Brava exibiram os maiores niveis de resistência e as menores reduções no rendimento de grãos, enquanto URS 22 teve a maior suscetibilidade, com redução superior a $70 \%$ no rendimento de grãos. Os resultados obtidos superam os impactos negativos da doença previamente relatados em aveia, particularmente em relação ao rendimento de grãos. Os dados apresentados neste trabalho ressaltam a importância da resistência genética, particularmente a parcial, na manutenção do potencial genético produtivo, na redução de contaminações ambientais pelo menor uso de fungicidas e na ampliação dos ganhos econômicos com a cultura da aveia.

Palavras-chave: Avena sativa, Puccinia coronata f. sp. avenae, resistência genética, análise econômica.

\section{INTRODUCTION}

Oat (Avena sativa L.), a member of the Poaceae family, is used for human consumption and animal feed. It is an excellent option for crop succession systems in subtropical regions, as those adopted in Southern Brazil with soybean and maize, as well as in the maintenance of no- tilling systems. In the last 44 years, the average oat grain yield in Brazil increased more than twofold, and the cultivated area nearly 10-fold, expanding the production 14-fold (CONAB, 2019). The cultivated area in 2019 was 396.4 thousand ha, producing 933.2 thousand $\mathrm{Mg}$, the equivalent to an average yield of $2.3 \mathrm{Mg} \mathrm{ha}^{-1}$ (CONAB, 2019).

Crown rust, caused by Puccinia coronata f. sp. avenae Led. \& Fraser, is the main and most destructive oat disease in Brazil, Argentina and 
Uruguay (LEONARD \& MARTINELLI, 2005). It spreads in all oat cultivated areas, and limits grain production and quality (MARTINELLI et al., 1994). Genetic resistance is the most efficient method for disease management, since it does not require additional costs and avoids environmental contamination (NAZARENO et al., 2018). Genetic resistance to $P$. coronata can be race-specific or non-race-specific (CARSON, 2011; LEONARD, 2002). The racespecific resistance is based in the gene-for-gene interaction (FLOR, 1971). It is conferred by one or a few genes and, in general, it triggers hypersensitive responses that may inhibit pathogen growth. However, due to the high evolutive potential of $P$. coronata (CARSON, 2011) and selection pressure for pathogen virulence, the race-specific resistance has been quickly overcome (LEONARD, 2002). The non-racespecific resistance is incomplete, generally promoted by several minor genes, where the host shows some level of susceptibility but the disease progress is limited (PARLEVLIET, 1979). Its main effects are longer latent period, lower infection frequency, pustule size and infectious period (ADMASSU-YIMER et al., 2018; RUWALI et al., 2013).

In Southern Brazil the high genetic variability for virulence in $P$. coronata populations (VIEIRA et al., 2007) and the outstanding environmental conditions for pathogen development cause the genetic resistance of cultivars to be overcome faster. Therefore, characterization and identification of new resistance sources is vital, becoming the focus of many studies worldwide (ADMASSU-YIMER et al., 2018; HUSSAIN et al., 2019, PRZYSTALSKI et al., 2013). Nevertheless, there is a lack of information about the disease's impact on yield and grain quality. The objective of this study was to characterize the resistance of six oat genotypes to crown rust and to evaluate the economic impact caused by the disease in a favorable environment, such as the Southern Brazil.

\section{MATERIAL AND METHODS}

Field experiments were conducted at the experimental station of the Federal University of Rio Grande do Sul (UFRGS), Eldorado do Sul, RS, Brazil $\left(30^{\circ} 05^{\prime} 22^{\prime \prime}\right.$ S, $51^{\circ} 39^{\prime} 08^{\prime \prime} \mathrm{W}, 46 \mathrm{~m}$ above sea level; humid subtropical climate with an average annual precipitation of $1400 \mathrm{~mm}$ ). The experiments were sown at two different dates, aiming two distinct environmental conditions (temperature, pluviosity), being the first on 15/06/2018 (environment 1) and the second on 13/07/2018 (environment2). Environmental data for both conditions were obtained by a stationary meteorological station located at the experiment site. Seed density was 350 plants $\mathrm{m}^{2}$. The cultivars used and their genealogy are shown in table 1. Crop management followed technical recommendations except for the fungicide application.

The fungicide used was Folicur $^{\circ}$ (Tebuconazole $200 \mathrm{~g} \mathrm{~L}^{-1}, 21.3 \% \mathrm{~m} / \mathrm{v}$ ). It was sprayed with a backpack sprayer when the incidence of plants with sporulating pustules was between 15 and $30 \%$, repeated when the same criteria was reached. The economic analysis of chemical control considered the fungicide commercial price (22.06 US $\$ \mathrm{~L}^{-1}$ of commercial product) and the operation costs, being the combination of: tractor $(86 \mathrm{cv})$ and trailed sprayer (14 m), operating at $12 \mathrm{~km} \mathrm{~h}^{-1}$ with $85 \%$ efficiency, is US\$ $2.47 \mathrm{ha}^{-1}$. At each application $0.75 \mathrm{~L} \mathrm{ha}^{-1}$ of Folicur ${ }^{\circ}$ were used, i.e. US\$ $16.80 \mathrm{ha}^{-1}$, meaning a fungicide spraying costs US\$ $16.80+2.47$, or US\$19.27 ha ${ }^{-1}$.

The disease severity was visually estimated based on the modified scale of Cobb (PETERSON et al., 1948), from the disease onset until the end of the plant cycle. The number of evaluations varied from 16 in environment 1 to 17 in environment 2. The last evaluation defined the final severity. The area under the disease progress curve (AUDPC) was calculated using the severity values along the plant cycle. AUDPC values were normalized and corrected using the equation proposed by Fry (1978) and adapted by Graichen et al. (2010). The apparent infection rate was calculated based on disease severity along the time. The data was linearized by the equation $\ln (\mathrm{x} /(1-\mathrm{x}))$, where $\mathrm{x}$ is the disease severity at each evaluation point, and plotted against the number of days after emergence. A linear regression was obtained and its angular coefficient represented the apparent infection rate (VANDERPLANK, 1963). Pustule length was measured in flag-leaf under a stereo microscope (Leica MZ). Five biological replicates were evaluated, each containing at least 80 pustules, representing 400 pustules per genotype.

The grain yield was expressed in 13\% humidity. Grain hectoliter mass was estimated in a hectoliter scale, and the mass of thousand grains weighed in an analytical scale. The economic impact of the disease was calculated as yield reduction, considering the oat's market price as US\$ $136.25 \mathrm{Mg}^{-1}$.

The experimental design was randomized blocks, in a factorial system of $6 \times 2 \times 2$ (genotype $\times$ environment $x$ chemical control), with five replicates and a total of 120 sampling units. Each sampling unit was composed by five lines $(3 \mathrm{~m}), 0.2 \mathrm{~m}$ apart from each other. The units inside the block were $0.4 \mathrm{~m}$ apart and intercalated by the same area sown with the 
Table 1 - Genealogy of used oat genotypes (Avena sativa), number of fungicide sprays, growth stages at spraying, economic analysis, and Pearson's correlation between productivity traits and disease response traits in oats grown in two field environments under naturally infected crown rust. AUDPC (area under the disease progress curve).

\begin{tabular}{|c|c|c|c|c|c|c|c|c|c|}
\hline \multirow[t]{2}{*}{ Genotype } & \multicolumn{2}{|c|}{ Genealogy } & Additional genealogy & \multicolumn{3}{|c|}{$\mathrm{N}^{0}$ of fungicide sprays } & \multirow[b]{2}{*}{ Stages } & \multicolumn{2}{|c|}{$\begin{array}{l}\text { Chemical control } \\
\text { cost }{ }^{*} \text { US\$ }\end{array}$} \\
\hline & & & & $\begin{array}{c}\text { Env } \\
1^{\#}\end{array}$ & Stages $^{\Psi}$ & $\begin{array}{c}\text { Env } \\
2\end{array}$ & & Env 1 & Env 2 \\
\hline URS 22 & \multicolumn{2}{|c|}{$\begin{array}{l}\text { UFRGS } 841110 x \\
\text { UFRGS } 884021-1\end{array}$} & & 4 & $17,47,75,85$ & 4 & $\begin{array}{c}14,47,59 \\
75\end{array}$ & 77.16 & 77.16 \\
\hline URS 21 & \multicolumn{2}{|c|}{$\begin{array}{l}\text { UFRGS } 10 \mathrm{x} \\
\text { CTC84B993 }\end{array}$} & $\begin{array}{c}\text { CTC 84B993 = CI } 8235 \\
/ \text { Ken631 / MN720183 }\end{array}$ & 3 & $17,65,75$ & 4 & $\begin{array}{c}15,47,59 \\
75\end{array}$ & 57.85 & 77.16 \\
\hline URS Altiva & \multicolumn{2}{|c|}{$\begin{array}{l}\text { UFRGS 995090-2 } \\
\text { x URS } 21\end{array}$} & $\begin{array}{c}\text { UFRGS } 995090-2= \\
\text { UFRGS 881971// } \\
\text { Pc68/*5 Starter F4 }\end{array}$ & 3 & $17,65,75$ & 4 & $\begin{array}{c}15,47,59 \\
75\end{array}$ & 57.85 & 77.16 \\
\hline URS Brava & \multicolumn{2}{|c|}{$\begin{array}{c}\text { UFRGS 995078-2 } \\
\text { x URS } 21\end{array}$} & $\begin{array}{l}\text { UFRGS } 995078-2= \\
\text { UFRGS } 10 \text { X PAUL }\end{array}$ & 2 & 19,85 & 2 & 16,47 & 38.54 & 38.54 \\
\hline $\begin{array}{l}\text { UFRGS } \\
166091-2\end{array}$ & \multicolumn{2}{|c|}{$\begin{array}{c}\text { 07BT306 } \\
x \text { URS GURIA }\end{array}$} & & 1 & 75 & 1 & 47 & 19.27 & 19.27 \\
\hline $\begin{array}{l}\text { UFRGS } \\
\text { 16Q6030-2 }\end{array}$ & \multicolumn{2}{|c|}{$\begin{array}{l}\text { UFRGS 105064-1 } \\
\text { x SD81085 }\end{array}$} & & 0 & - & 0 & - & 0 & 0 \\
\hline \multicolumn{2}{|c|}{ Pearson's correlation } & Final rust severity & severity & 1000-grain mass & \multicolumn{3}{|c|}{ Hectolitre mass } & \multicolumn{2}{|c|}{ Grain yield } \\
\hline \multirow{2}{*}{\multicolumn{2}{|c|}{ AUDPC }} & & $93 \cdot$ & $-0,63$ & \multicolumn{3}{|c|}{$-0,45$} & \multicolumn{2}{|c|}{$-0,93$} \\
\hline & & \multicolumn{2}{|c|}{$2,39 \times 10^{-27 \alpha}$} & $8,81 \times 10^{-8}$ & \multicolumn{3}{|c|}{0,0003} & \multicolumn{2}{|c|}{$1,17 \times 10^{-27}$} \\
\hline \multirow{2}{*}{\multicolumn{2}{|c|}{ Final rust severity }} & & & $-0,53$ & \multicolumn{3}{|c|}{$-0,28$} & \multicolumn{2}{|c|}{$-0,89$} \\
\hline & & \multicolumn{3}{|c|}{0,00002} & \multicolumn{3}{|c|}{0,03} & \multicolumn{2}{|c|}{$1,53 \times 10^{-21}$} \\
\hline $1000_{\text {- }}$ rain & & & & & & 0,42 & & 0,6 & \\
\hline 1000-grain $\mathrm{m}$ & & & & & & 0,0009 & & $8,47 x$ & \\
\hline & & & & & & & & 0,5 & \\
\hline Hectoliter ma & & & & & & & & $2,84 x$ & \\
\hline
\end{tabular}

${ }^{*}$ Commercial value of the fungicide (Folicur $200 \mathrm{EC}^{\circledR}$ - Tebuconazole: $200 \mathrm{~g} \mathrm{~L}^{-1}, 21.3 \% \mathrm{w} / \mathrm{v}$ ) plus application considered US\$19.27 ha ${ }^{-1}$.

${ }^{\#}$ Env indicates different environmental conditions caused by different sowing dates.

${ }^{\Psi}$ Plant growth stages at the moment of each fungicide application (ZADOKS et al., 1974).

-Pearson's Correlation Coefficient.

${ }^{\alpha} \mathrm{P}$ value (significance).

immune genotype UFRGS 146171-1, used as border. Blocks were $1 \mathrm{~m}$ apart from each other.

Data was submitted to Liliefors' normality test and analysis of variance. Means were compared by Tukey's test $(p \leq 0,05)$. Pearson's correlation $(p \leq 0,05)$ was calculated between AUDPC, final severity, hectoliter mass, thousand grain mass, and grain yield. Grain yield regression analysis against AUDPC was carried out for each genotype to predict yield loss. Sisvar version 5.6 (FERREIRA, 2011) and SigmaPlot version 12.5 from Systat Software, Inc., San Jose California USA, were used for statistical analysis.

\section{RESULTS}

\section{Epidemy and resistance evaluation}

The epidemic duration varied between environments (Figure 1A, 1B). It lasted 60 days in environment 1, beginning at 51 days after emergence (dae) and ending at 111 dae; on UFRGS 166091-2 the disease started later at 96 dae, reaching $16.6 \%$ of severity. URS Altiva, URS 21 and URS Brava attained $89.4,77.4$ and $22.4 \%$ of severity, respectively. On URS 22 , the severity reached $100 \%$ at 100 dae, causing early senescence and plant death. Crown rust did not develop on UFRGS 16Q6030-2 in any environment (Figure 1A, 1B and 1E). The epidemy lasted 69 days, from 25 to 94 dae in environment 2, starting 26 days earlier. On URS 22, URS Altiva, URS 21 and URS Brava the final severity was 100 , $85.2,67.2$ and $24.2 \%$, respectively. But on UFRGS 166091-2, the disease period was from 67 dae to 94 dae, ending with $18.8 \%$ severity only (Figure 1B).

Disease progress expressed as AUDPC was higher in URS 22 at both environments. The 


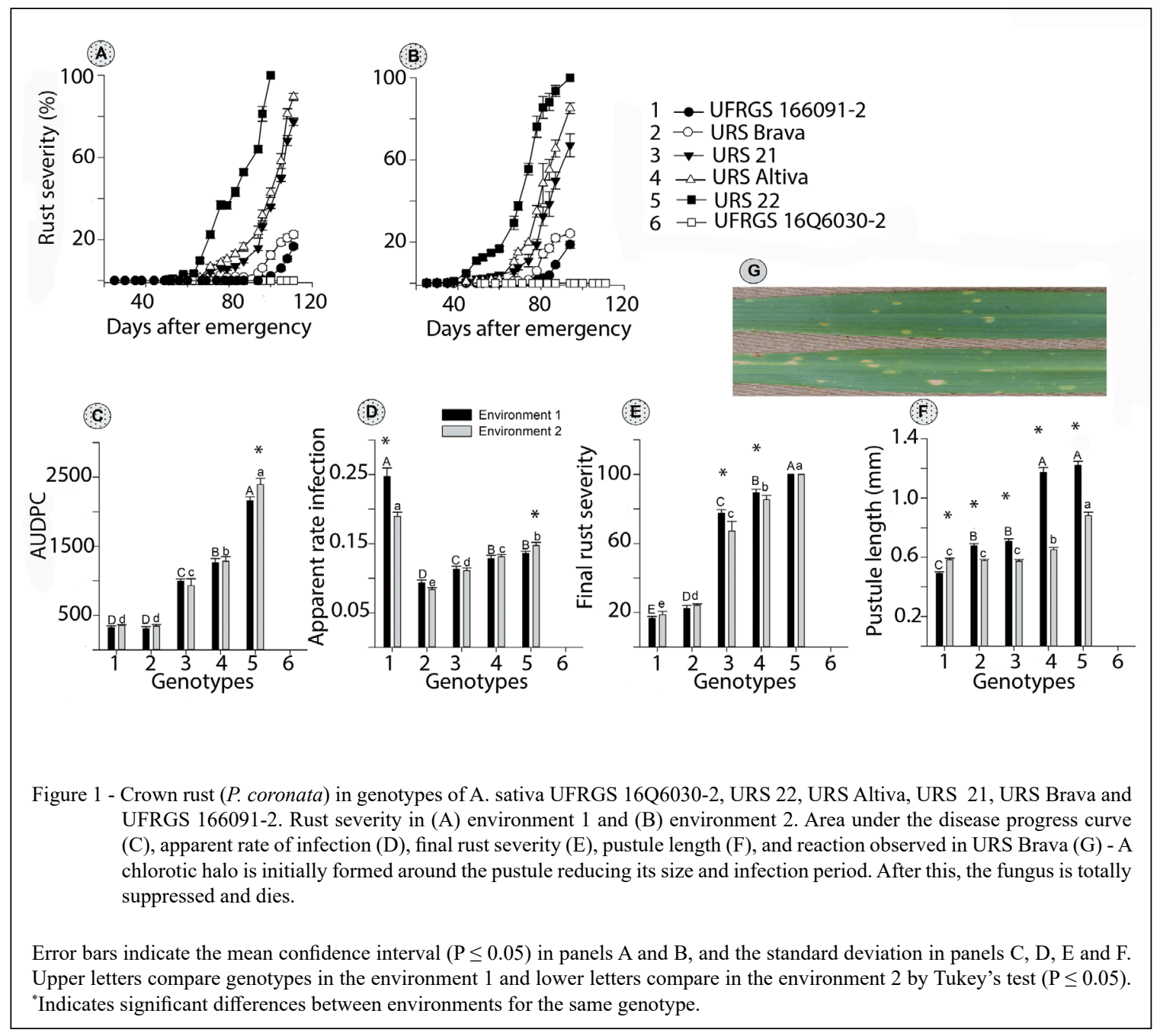

smallest AUDPC values were obtained in URS Brava and UFRGS 166091-2, being 85.5\% smaller than that obtained in URS 22 (Figure 1C). However, those genotypes had opposite behavior for apparent infection rate. The URS Brava had the smallest rate whereas UFRGS 166091-2 exhibited the highest one in both environments (Figure 1D).

Pustule size was affected by the environment. Pustules were larger in environment 2 on UFRGS 166091-2, and in environment 1 on the other genotypes. The highest pustule size was observed on URS 22, without differing from URS Altiva in environment 1. The smallest size in environment 1 was exhibited on UFRGS 166091-2 and, in environment 2 on URS 21, URS Brava and UFRGS 166091-2 (Figure 1F). Under these field conditions the genotype UFRGS 16Q6030-2 was characterized as immune, URS 22 as susceptible, and the others were intermediately affected, with partial levels of resistance.

\section{Productivity}

The effective number of fungicide sprays; and therefore, the chemical control costs varied among genotypes and environments (Table 1). The highest number of sprays was four, being required by URS 22 in both environments, and by URS Altiva and URS 21 in environment 2, but they required a smaller amount of sprays in environment 1. URS Brava and UFRGS 166091-2 always needed smaller number of applications, two and one, respectively. Interestingly, in environment 1, UFRGS 166091-2 required spraying at growth stage 75 , but earlier in environment 2 , at stage 47 according to Zadok's scale (Table 1). There was no need to spray UFRGS 16Q6030-2. Data referring to the costs of chemical control are summarized in table 1. 
When the disease was chemically controlled, higher grain yield was obtained in environment 1, averaging 4.65 $\mathrm{Mg} \mathrm{ha}^{-1}$, compared to $3.95 \mathrm{Mg} \mathrm{ha}^{-1}$ in environment 2. Grain yield variation was low (4.21 to $4.97 \mathrm{Mg} \mathrm{ha}^{-1}$ in environment 1) among genotypes (Figure 2A). In the absence of chemical control there was a significant variation in grain yield among genotypes (0.92 to $4.96 \mathrm{Mg} \mathrm{ha}^{-1}$ ) and environments (Figure 2B). UFRGS 16Q6030-2 showed similar grain yield and quality in both conditions (Figure 2). UFRGS 166091-2 and URS Brava had the smallest AUDPC values and reduction in grain yield, with 7.2 and $13.3 \%$, respectively in environment 1 , and 6.7 and $13.2 \%$ in environment 2 (Figure 2C). URS 21 and URS Altiva exhibited intermediate reductions (34 and 40\% in environment 1 , and 32.6 and $30 \%$ in environment 2 , respectively). The greatest yield loss was on URS 22 (70 and $75.3 \%$ ), causing in average a revenue reduction of US\$ $507.16 \mathrm{ha}^{-1}$. The URS 22 yield reduction was 10 times greater to that on UFRGS 166091-2 (Figure 2C).

Genotypes reduced their hectoliter mass in environment 2 independently of chemical control, and the smallest hectoliter mass was shown by UFRGS 166091-2 and by URS 22, with and without chemical control, respectively (Figure 2D and 2E). UFRGS 16Q6030-2 showed the smallest reduction between environments. UFRGS 166091-2 and URS Brava, as observed for grain yield, exhibited the lowest reductions in hectoliter mass due to the disease, being the largest reduction on the susceptible URS 22, with an average of $34 \%$ (Figure $2 \mathrm{E}$ ).

Under chemical control UFRGS 16Q60302, URS 22 and URS 21 showed higher thousand grains mass in environment 1; although, the opposite was noted for URS Brava and UFRGS 166091-2. URS Altiva kept the same thousand grain mass in both environments (Figure 2D). Without chemical control the thousand grain mass was higher in environment 2 for all genotypes except UFRGS 16Q6030-2 (Figure 2F). The highest values for thousand grain mass were obtained by UFRGS 16Q6030-2 and URS Altiva, independently of chemical treatment and environments (Figure $2 \mathrm{G}$ and $2 \mathrm{H}$ ). The loss in thousand grain mass caused by the disease was smaller in UFRGS 160991-2 and URS Brava, representing 3.9 and $3.5 \%$ loss in environment 1 and 3.3 and $2.4 \%$ in environment 2 , respectively. The highest loss was in URS 22, about 35 and $28 \%$ in environment 1 and 2 , respectively (Figure 2I).

No chemical control caused losses in grain yield (Figure 2C), hectoliter (Figure 2F) and thousand grain mass (Figure 2I), but the magnitude varied accordingly to the resistance level of each genotype and environment.

Pearson correlation of AUDPC and final severity was highly negative to yield. Hectoliter and thousand grain mass also showed negative but moderate correlation to AUDPC and final severity (Table 1).

\section{DISCUSSION}

The environmental conditions in Southern Brazil favor $P$. coronata development, as observed in the susceptible genotype URS 22, being adequate for crown rust resistance evaluation (GRAICHEN et al., 2011). Results evidenced the significant impact of crown rust on oat yield and grain quality in susceptible genotypes. Losses were inversely proportional to the resistance level.

The immunity of UFRGS 16Q6030-2 may indicate race-specific resistance, as reported in varieties released in the past. If promoted by one or a few genes, it may induce a strong selection pressure for virulence on the pathogen population, becoming ephemera (CARSON, 2011). Race-specific resistance quickly overcome in genotypes from Southern Brazil is a consequence of the elevated evolutive potential of $P$. coronata and the great genetic variability for virulence in the pathogen populations (VIEIRA et al., 2007). The existence of a common epidemiological unit among the countries in the Southern Cone, especially Brazil, Argentina and Uruguay, with continuous and cyclic dissemination of uredospores in the region, also aggravates the situation (LEONARD \& MARTINELLI, 2005). Moreover, Avena spp. and Lolium multiflorum are cultivated along the year, creating "green bridges" between seasons, and allowing survival, multiplication and fixation of new and more complex races of crown rust.

URS 22, released in 2001 as immune, had its resistance overcame in a short time, exhibiting high susceptibility since. Similarly, URS 21, released at the same year as immune, kept that immunity for only a few years but, in contrast to URS 22, showed a high level of race-non-specific resistance, which was durable, sensu JOHNSON (1981), in the field for at least 14 years (FIGUEIRÓ et al., 2017).

URS Brava and URS Altiva were released as cultivars in 2014 and 2015, respectively, with phenotypic traits of race-non-specific resistance to crown rust (FEDERIZZI et al., 2015; NAVA et al., 2016). URS Altiva was more susceptible when compared to URS Brava and URS 21. The URS 21 's higher resistance might be due to higher genetic 


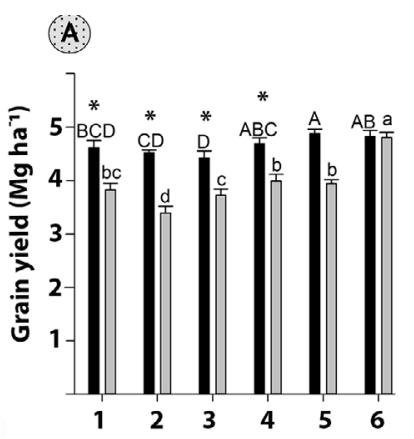

(D)
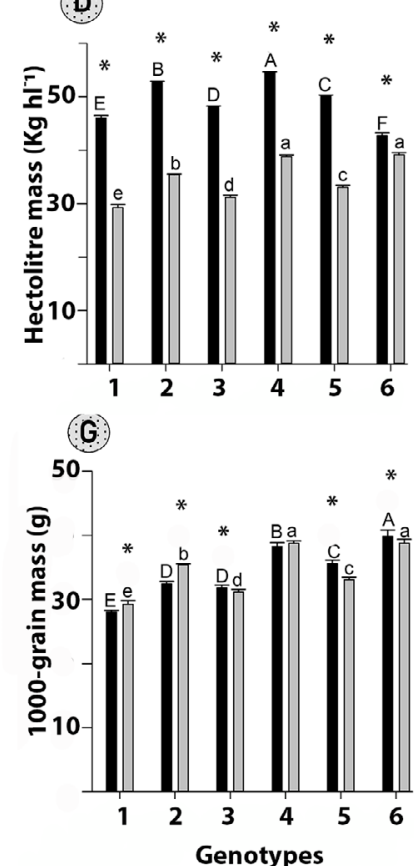

ij:

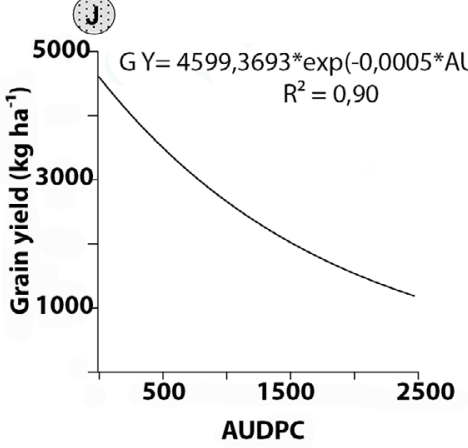

(B)

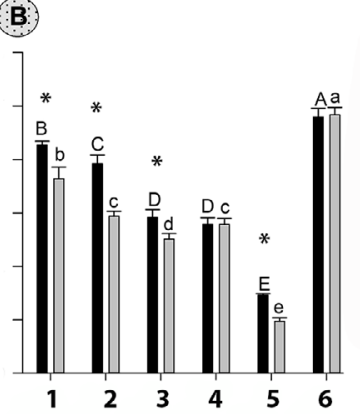

(E)

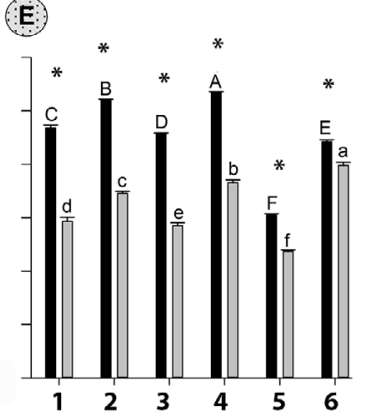

(H)

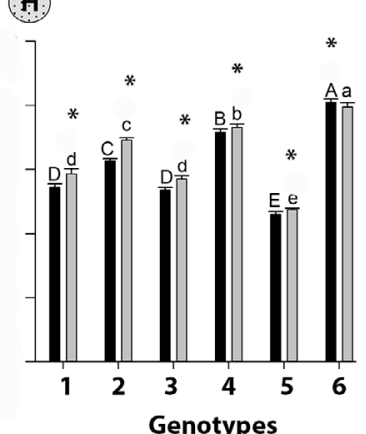

(b)

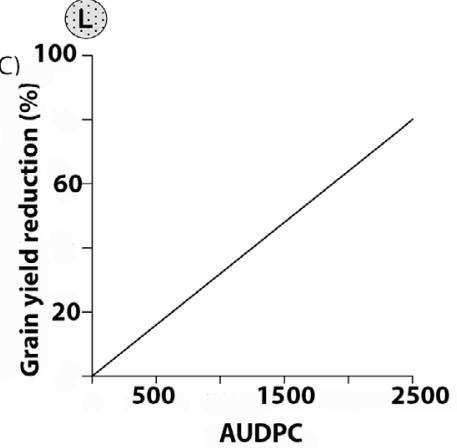

c)

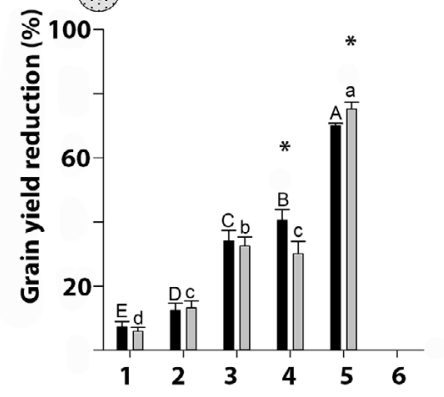

(A)
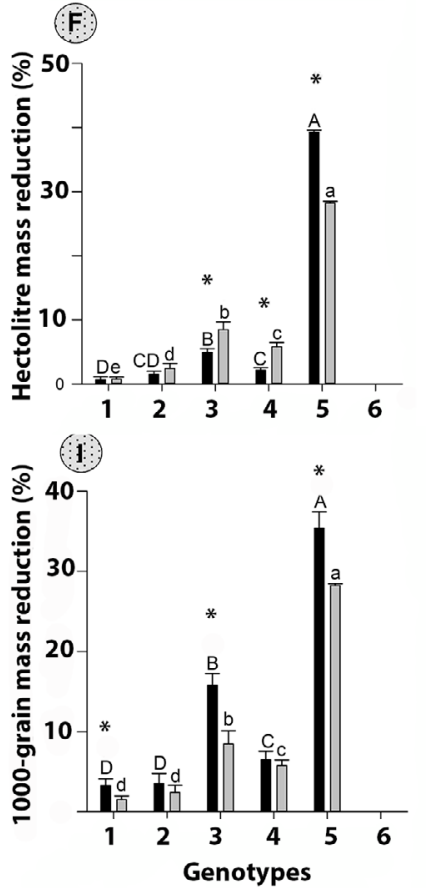

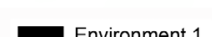

Genotypes:

1 UFRGS 166091-2

2 URS Brava

3 URS 21

4 URS Altiva

5 URS 22

6 UFRGS 16Q6030-2

Figure 2 - Changes in grain traits due to crown rust disease in A. sativa genotypes with different genetic resistances evaluated in two environments. Grain yield with (A) and without chemical control (B), grain yield reduction by the disease $(C)$; hectoliter mass with (D) and without chemical control (E), hectoliter mass reduction by the disease $(\mathrm{F})$; 1000-grain mass with $(\mathrm{G})$ and without chemical control $(\mathrm{H}), 1000$-grain mass reduction by the disease (I); Regression between the area under the disease progress curve (AUDPC) and grain yield (J) and prediction of grain yield reduction by increase of the area under the disease progress curve (AUDPC) (L).

Error bars indicate the standard deviation in panels A to I. Upper letters compare genotypes in the environment 1 and lower letters compare in the environment 2 by Tukey's test $(\mathrm{P} \leq 0.05)$. "Indicates significant differences between environments for the same genotype.

Ciência Rural, v.51, n.3, 2021. 
resistance complexity, being associated to two major loci with partial dominance and three minor loci with complete dominance (ZAMBONATO et al., 2012). URS Brava and URS Altiva derived from crosses with URS 21. Both URS Brava genitors have UFRGS 10 in their genealogy (Table 1), an important source of resistance to crown rust, which might explain the greater resistance detected in URS Brava.

Similar AUDPC may not mean similar resistance type. That was observed in UFRGS 166091-2 and URS Brava; despite similar AUDPC, they had different epidemic periods, being smaller for UFRGS 166091-2 (Figure 1C). It means that this last genotype had a greater disease progress rate, with an accentuated disease growth. Characteristically, it indicates the resistance was already overcome, probably by a new race. This hypothesis is corroborated by the formation of pustules typically susceptible, which are not involved by chlorotic halos. Distinction of the phenotypic reactions may reveal several important traits. For example, URS Brava limited disease development by the formation of chlorotic halos surrounding the pustule, reducing its size and sporulation period (Figure 1G), which may indicate a race-non-specific resistance, a trait of interest for breeding programs.

Temperature is one of the most important environmental factors for rusts, usually favoring pathogen development (SIMONS, 1985). In wheat and flax, temperature increment is associated to changes in expression of some resistance genes (BROERS et al., 1996; ZHANG et al., 2017). The pustule size variation between environments suggested that the trait mechanism depends on the environment. Environment 2 had a longer epidemy and may have contributed to the resistance expression by reducing the pustule size. Between the 39th and 92th dae, the mean temperature was $15{ }^{\circ} \mathrm{C}$ in environment 1 and $18.6^{\circ} \mathrm{C}$ in environment 2 .

The grain yield reduction caused by crown rust in Southern Brazil could vary from 24 to $57 \%$ according to MARTINELLI et al. (1994) and REIS et al. (2008). In the present study we reported yield reduction to be greater than $70 \%$ in URS 22 . These results may partially explain the low oat yield average in the country, about $2.3 \mathrm{Mg} \mathrm{ha}^{-1}$, when the potential yield is higher than $4 \mathrm{Mg} \mathrm{ha}^{-1}$. In the conditions of this study, URS 22 exhibited reductions of 35 and $39 \%$ in the thousand grains and hectoliter mass, much higher than those reported by REIS et al. (2008), with $17 \%$ and $21 \%$ for the same traits, respectively. All traits related to yield were affected by the environment, with environment 1 favoring yield for the majority of the genotypes (Figure 2). Hectoliter mass was negatively affected by environment 2 . This trait is very sensitive to changes in temperature and pluviosity during grain development (NEL et al., 1998), the differences in rain might explain its reduction, environment 2 had half the amount of rain of environment 1, 62.8 and $134.8 \mathrm{~mm}$, respectively. The final severity negatively correlated to all yield traits confirms the devastating effects of disease (Table 1). Every increase of 100 units in AUDPC causes in average 3.2\% reduction in grain yield (Figure $2 \mathrm{~L}$ ).

Genetic variability for crown rust resistance has been reported for several years (CHAVES et al., 2004; GRAICHEN et al., 2011) as observed in our results. Once again it is shown that the most costeffective way is to manage the disease through the use of resistant cultivars. This can be shown by the reduction in the number of sprays required by genotypes with resistance when compared to those susceptible (Table 1). Partial resistance reduced the number of sprays, and also the economic costs of disease control. By controlling the disease with Folicur $^{\odot}$ in this research, URS 22 represented a cost of US\$ $77.16 \mathrm{ha}^{-1}$. This value was $25 \%$ less for the partially resistant cultivars URS Altiva and URS 21 in the environment 2, 50\% for URS Brava and $75 \%$ for UFRGS 166091-2. UFRGS 16Q6030-2 allowed for $100 \%$ cost reduction since it was immune and did not required spraying. The use of partially resistant cultivars requiring only one fungicide spraying for disease control, in the Brazilian oat area of 394,000 ha, may result in savings of US\$ $22,859,880.00$ in only one season, and may avoid the usage of up to $886,500 \mathrm{~L}$ of fungicide in comparison to the four sprayings needed in susceptible cultivars. It is worth mentioning that Folicur $^{\odot}$ cost is about $50 \%$ less than that of modern fungicides that use more complex formulations. Consequently, the economic potential of the above example could reach up to US\$ $45,000,000.00$ per crop season in Southern Brazil.

\section{CONCLUSION}

The results obtained in this study surpass the crown rust impacts previously reported, especially those related to grain yield, having reached $73 \%$ of loss in susceptible genotypes. Moreover, they characterized the presence of partial resistance in two among six oat genotypes. In addition, they also highlighted the importance of genetic resistance, particularly the race non-specific, partial resistance, in the maintenance of the yield potential of cultivars, reducing environmental impacts and amplifying 
economic gains with the oat crop for the challenging southern Brazilian environment.

\section{DECLARATION OF CONFLICT OF INTERESTS}

The authors declare no conflict of interest. The founding sponsors had no role in the design of the study; in the collection, analyses, or interpretation of data; in the writing of the manuscript, and in the decision to publish the results.

\section{ACKNOWLEDGEMENTS}

We thank FAPERGS/CNPq (grant $\mathrm{N}^{\circ} .16 / 2551$ 0000484-6-Pronex) for the financial support; CNPq for fellowships to CAD (301642/2018-4), LCF and GBPS; and CAPES, Brazil Finance code 001 and UFRGS/PROPESQ for the scholarships to $\mathrm{ML}$ and $\mathrm{FKC}$, respectively.

\section{AUTHORS' CONTRIBUTIONS}

CAD, JAM, MTP, LCF and ML conceived and designed experiments. ML, GBPS and FKC carried out data collection and statistical analyses. CAD, JAM and ML prepared the draft of the manuscript. All authors critically revised the manuscript and approved of the final version.

\section{REFERENCES}

ADMASSU-YIMER, B. et al. New sources of adult plant and seedling resistance to Puccinia coronata f. sp. avenae identified among Avena sativa accessions from the national small grains collection. Plant Disease, v.102, n.11, p.2180-2186, 2018. Available from: <https://doi.org /10.1094/PDIS-04-18-0566-RE>. Accessed: Jun. 13, 2019. doi: 10.1094/PDIS-04-18-0566-RE.

BROERS, L. H. M. et al. Field assessment of quantitative resistance to yellow rust in ten spring bread wheat cultivars. Euphytica, v.90, n.1, p.9-16, 1996. Available from: <https://doi. org/10.1007/ BF00025154>. Accessed: Jun. 12, 2019. doi: 10.1007/BF00 025154 .

CARSON, M. L. Virulence in oat crown rust (Puccinia coronata f. sp. avenae) in the United States from 2006 through 2009. Plant Disease, v.95, n.12, p.1528-1534, 2011. Available from: <https:// doi.org/10.1094/PDIS-09-10-0639>. Accessed: Aug. 12, 2019. doi: 10.1094/PDIS-09-10-0639.

CHAVES, M. S. et al. Quantitative resistance to crown rust in white oat genotypes: II - Evaluation of resistance components. Fitopatologia Brasileira, v.29, n.1, p.43-51, 2004. Available from: $<$ https://www.scielo.br/scielo.php?script $=$ sci_arttext\&pid=S010041582004000100008\&lng=en\&nrm=iso $>$. Accessed: Aug. 12, 2019. doi:10.1590/S0100-41582004000100008.

CONAB - COMPANHIA NACIONAL DE ABASTECIMENTO Safra 2018/2019: quarto levantamento. Acompanhamento da safra brasileira: grãos, Brasília, v.6, n.4, p.93-95. 2019 Monitoramento agrícola. Projeto Observatório Agrícola.

FEDERIZZI, L. C. et al. URS Brava - a new oat cultivar with partial resistance to crown rust. Crop Breeding and Applied
Biotechnology, v.15, p.197-202, 2015. Available from: $<$ https://www.scielo.br/scielo.php?script=sci_arttext\&pid $=$ S1984-70332015000300197 $>$. Accessed: Aug. 12, 2019. doi: 10.1590/1984-70332015v15n3c35.

FERREIRA, D. F. Sisvar: a computer statistical analysis system. Ciência e Agrotecnologia, v.35, p.1039-1042, 2011. Available from: $<$ https://doi.org/10.1590/S1413-70542011000600001>. Accessed: Jan. 12, 2019. doi: 10.1590/S1413-70542011 000600001.

FIGUEIRÓ, A. A. et al. RNAseq analysis reveals the role of secondary metabolism in the response of URS 21, a racenonspecific resistant cultivar, to crown rust. Plant Pathology, v.66, n.5, p.702-712, 2017. Available from: $<$ https://bsppjournals. onlinelibrary.wiley.com/doi/full/10.1111/ppa.12615>. Accessed: Jan. 12, 2019. doi: 10.1111/ppa.12615.

FLOR, H. H. Current Status of the Gene-For-Gene Concept. Annual Review of Phytopathology, v.9, n.1, p.275-296, 1971. Available from: <https://oi.org /10.1146/annurev. py.09.090171.001423>. Accessed: Jan. 12, 2019. doi: 10.1146/ annurev.py.09.090171.001423.

FRY, W. E. Quantification of general resistance of potato cultivars and fungicide effects for integrated control of potato late blight. Phytopathology, v.68, p.1650-1655, 1978. Available from: $<$ https://doi.org/10.1094/Phyto-68-1650>. Accessed: Jan. 12 , 2019. doi: 10.1094/Phyto-68-1650.

GRAICHEN, F. A. S. et al. Inheritance of resistance to oat crown rust in recombinant inbred lines. Scientia Agricola, v.67, p.435-440, 2010. Available from: <https:// www.scielo.br/scielo.php? script $=$ sci arttext\&pid $=S 0103$ 90162010000400010\&lang=pt $>$. Accessed: Jan. 12, 2019. doi: 10.1590/S0103-90162010000400010.

GRAICHEN, F. A. S. et al. Epidemiological and histological components of crown rust resistance in oat genotypes. European Journal of Plant Pathology, v.131, n.3, p.497-510, 2011. Available from: $<$ https://link.springer.com/article/10.1007/ s10658-011-9825-z>. Accessed: Jan. 12, 2019. doi: 10.1007/ s10658-011-9825-Z

HUSSAIN, M. et al. Field based variability in oat crown rust (Puccinia coronata f. sp. avenae) resistance in exotic oat germplasm. Sarhad Journal of Agriculture, v.35, n.2, 2019. Available from: <https://doi.org/10.17582/journal. sja/2019/35.2.459.466>. Accessed: Nov. 15, 2019. doi: 10.17582/ journal.sja/2019/35.2.459.466

JOHNSON R. Durable Resistance: Definition of, Genetic Control, and Attainment in Plant Breeding. Phytopathology, v.71, p.567, 1981. Available from: <https://www.apsnet.org/ publications/phytopathology/backissues/Documents/1981Articles/ Phyto71n06 567.PDF>. Accessed: Nov. 15, 2019. doi: 10.1094/ Phyto-71-567.

LEONARD, K. J. Oat lines with effective adult plant resistance to crown rust. Plant Disease, v.86, n.6, p.593-598, 2002. Available from: <https://doi.org/10.1094/PDIS.2002.86.6.593>. Accessed: Feb. 12, 2019. doi: 10.1094/PDIS.2002.86.6.593.

LEONARD, K. J.; MARTINELLI, J. A. Virulence of oat crown rust in Brazil and Uruguay. Plant Disease, v.89, n.8, p.802-808, 2005. Available from: $<$ https://apsjournals.apsnet.org/doi/10.1094/ PD-89-0802>. Accessed: Feb. 12, 2019. doi: 10.1094/PD-89-0802. 
MARTINELLI, J. A. et al. Yield reductions of oat grains due leaf rust severity. Summa Phytopathologica, v.20, n.2, p.116118, 1994.

NAVA, I.C. et al. URS Altiva - a new oat cultivar with high agronomic performance. Crop Breeding and Applied Biotechnology, v.16, p.254-260, 2016. Available from: <https://www.scielo.br/ scielo.php?script=sci_arttext\&pid=S1984-70332016000300254>. Accessed: Feb. 12, 2019. doi: 10.1590/1984-70332016v16n3c39.

NAZARENO, E. S. et al. Puccinia coronata f. sp. avenae: a threat to global oat production. Molecular Plant Pathology, v.19, n.5, p.1047-1060, 2018. Available from: $<$ https://doi.org /10.1111/mpp.12608>. Accessed: Jan. 12, 2019. doi: 10.1111/ mpp. 12608 .

NEL, M. M. et al. Sources of variation for yield, protein content and hectolitre mass of spring wheat (Triticum aestivum L.) cultivars of the Western and Southern Cape. S. Afr. Tydskr. Plant Grond, v.15, n.2, p.72-79. 1998. Available from: <https://journals. co.za/content/plantsoil/15/2/AJA02571862_376>. Accessed: Jun. 23, 2020.

PARLEVLIET, J. E. Components of resistance that reduce the rate of epidemic development. Annual Review of Phytopathology, v.17, n.1, p.203-222, 1979. Available from: <https://doi. org/10.1146/annurev.py.17.090179.001223>. Accessed: Jan. 12, 2019. doi: 10.1146/annurev.py.17.090179.001223.

PETERSON, R. F. et al. A diagrammatic scale for estimating rust intensity on leaves and stems of cereals. Canadian Journal of Research, v.26, p.496-500, 1948. Available from: <https://doi. org/10.1139/cjr48c-033>. Accessed: Jan. 12, 2019. doi: 10.1139/ cjr48c-033.

PRZYSTALSKI, M. et al. A method for identifying oat varieties with improved resistance to oat crown rust from a series of field trials. Field Crops Research, v.149, p.49-55, 2013. Available from: <https://www.sciencedirect.com/science/ article/pii/S0378429013001354\#! >. Accessed: Jan. 12, 2019. doi: 10.1016/j.fcr.2013.04.010.
REIS, E. M. et al. Modelos de ponto crítico para estimar danos causados pela ferrugem da folha da aveia branca. Summa Phytopathologica, v.34, p.238-241, 2008. Available from: $<$ https://doi.org/S0100-54052008000300006 > Accessed: May, 12, 2019. doi: 10.1590/S0100-54052008000300006.

RUWALI, Y. et al. Screening for resistance to crown rust in oat genotypes through morphological and molecular parameters. Journal of Plant Pathology \& Microbiology, v.4, n.10, p.1000208, 2013. Available from: <https://doi.org/10.4172/2157-7471.1000208>. Accessed: Aug. 12, 2019. doi: 10.4172/2157-7471.1000208.

SIMONS, M. D. Crown rust. In: ROELFS, A.; BUSHNELL, W.(ed.). The cereal rusts: diseases, distribution, epidemiology, and control. Orlando:Academic Press, 1985. v.2, p.131-172.

VANDERPLANK, J. E. Plant diseases: epidemics and control. New York: Academic Press, 1963. 366p.

VIEIRA, E. A. et al. Virulence variability of Puccinia coronata f. sp. avenae isolates collected in three counties from Rio Grande do Sul State, Brazil. Plant Disease, v.91, n.1, p.66-70, 2007. Available from: $<$ https://doi.org/10.1094/PD-91-0066>. Accessed: Feb. 12, 2019. doi: 10.1094/PD-91-0066.

ZADOKS, J. C et al. A decimal code for the growth stages of cereals. Weed Research, vol.14, p.415-421, 1974.

ZAMBONATO, F. et al. Phenotypic and genetic characterization of partial resistance to crown rust in Avena sativa L. Crop Breeding and Applied Biotechnology, v.12, p.261-268, 2012. Available from: <https://www.scielo.br/scielo.php?script=sci_arttext\&pi $\mathrm{d}=$ S1984-70332012000400005>. Accessed: Feb. 12, 2019. doi: 10.1590/S1984-70332012000400005.

ZHANG, W. et al. Identification and characterization of Sr13, a tetraploid wheat gene that confers resistance to the Ug99 stem rust race group. Proceedings of the National Academy of Sciences, p.201706277, 2017. Available from: <https://www.pnas. org/content/114/45/E9483.long>. Accessed: Jul. 12, 2019. doi: $10.1073 /$ pnas. 1706277114 . 